\title{
TGF-BETA IN THE NATURAL HISTORY OF PROSTATE CANCER
}

\author{
Jamal Ahel ${ }^{1}$, Narcis Hudorović ${ }^{2}$, Višnja Vičić-Hudorović ${ }^{3}$ and Hrvoje Nikles ${ }^{4}$ \\ ${ }^{1}$ Dr Zaky Polyclinic for Internal Medicine and Urology, Zagreb, Croatia; \\ ${ }^{2}$ Department of Vascular Surgery, Sestre milosrdnice University Hospital Centre, Zagreb, Croatia; \\ ${ }^{3}$ Croatian Nursing Association, Zagreb, Croatia; ${ }^{4}$ Department of Abdominal Surgery, \\ Sestre milosrdnice University Hospital Centre, Zagreb, Croatia
}

\begin{abstract}
SUMMARY - All transforming growth factors beta (TGFß) are cytokines that regulate several cellular functions such as cell growth, differentiation and motility. They may also have a role in immunosuppression. Their role is important for normal prostate development. TGFß is active in the regulation of balance between epithelial cell proliferation and apoptosis through stromal epithelia via the androgen receptor action. TGF $\beta$ protects and maintains prostate stem cells, an important population necessary for prostate tissue regeneration. However, TGFß is shown to have a contrasting role in prostate tumor genesis. In the early stages of tumor development, TGFß acts as a tumor suppressor, whereas in the later stages, TGFß becomes a tumor promoter by inducing proliferation, invasion and metastasis. In this review, we outline complex interactions that TGFß-mediated signaling has on prostate tumor genesis, focusing on the role of these interactions during the course of prostate cancer and, in particular, during disease progression.
\end{abstract}

Key words: Transforming growth factor beta; Prostatic neoplasms; Disease progression; Receptors, androgen; Stem cells

\section{Introduction}

Prostate cancer is one of the most commonly diagnosed cancers and one of the leading causes of cancerrelated deaths among men in the developed world. It is generally a late onset disease with $63 \%$ of diagnosed men being 65 years of age and older. Prostate cancer is a significant health and social issue, potentiated by the continuously increasing life expectancy. Treatment options for men with prostate cancer have improved over years. With the introduction of prostate specific antigen (PSA) testing, an increasing number of men have been diagnosed, with a significant proportion being diagnosed in a much earlier stage of disease. This has significantly decreased the mortality rate; standard

Correspondence to: Narcis Hudorovic, $M D, P h D$, Department of Vascular Surgery, Sestre milosrdnice University Hospital Centre, Vinogradska c. 29, HR-10000 Zagreb, Croatia

E-mail: narcis.hudorovic@zg.t-com.hr

Received November 23, 2015, accepted October 22, 2018 prostatectomy surgery of localized disease has a relative 5-year survival rate approaching 100\%, while the relative 10-year and 15-year survival has increased to $93 \%$ and $79 \%$, respectively ${ }^{1}$. However, for patients diagnosed with recurrent or disseminated disease, treatment options are more limited. Many will undergo radiation or androgen deprivation therapies, providing a relatively low and short-term success. Eventually, most develop androgen-independent re-growth within 3 years, and ultimately succumb to the disease. Hence, there is a need to develop strategies for prevention and treatment of recurrent disease by targeting specific growth factors essential for tumor survival, with the aim to increase life expectancy of prostate cancer patients.

The prostate gland consists of basal and secretory luminal epithelial cells together with occasional neuroendocrine cells, underlain by the stromal compartment consisting of smooth muscle cells, fibroblasts, blood vessels, nerves and extracellular matrix. 
The prostate is a site of continuous production of several proteins that make up the components of the ejaculate. These include prostaglandin E (PGE) and transforming growth factor beta (TGFß) $)^{2,3}$. Both testosterone and its metabolite 5a-dihydrotestosterone (DHT) are essential for the healthy development and function of the prostate 4 , but these androgens require strict regulation indirectly mediated by the action of many growth factors ${ }^{5}$, with TGFß possibly playing the most significant role ${ }^{6}$.

Depending on the cellular context, different TGFßs also exhibit significant pleiotropic effects on cell proliferation, differentiation, migration and survival in many biological processes, including the development, tumorigenesis, fibrosis, and wound healing ${ }^{7-9}$.

In many cancers, TGFß plays opposing roles; initially they exhibit tumor suppressor function by inhibition of cellular growth and induction of apoptosis, whereas during tumor progression, TGFß play a tumor survival role as tumor cells lose their sensitivity to TGFß-mediated growth arrest but retain the ability to undergo epithelial-mesenchymal transition (EMT) correlating with increased invasiveness and metastases $^{9,10}$.

In the prostate, TGFß stimulates cellular differentiation and inhibits epithelial cell proliferation by inducing cellular apoptosis and maintaining dormancy of prostatic stem cell ${ }^{6,11}$. High levels of TGFß1 were found in the serum and tumors of patients with prostate cancer and this is associated with a more aggressive disease, including increased angiogenesis, as well as a metastatic potential. The concomitant loss of TGFß receptor expression in malignant tissues renders them resistant to the anti-proliferative and proapoptotic effects of TGFß12-14, and is associated with poor prognosis ${ }^{15}$. Furthermore, TGFß1 secreted by tumors can function as a potent immunosuppressive agent, thus facilitating tumor growth ${ }^{16,17}$.

\section{Prostate Tumorigenesis and Pathogenesis}

Progression of prostate cancer is the result of accumulation of somatic, genetic and epigenetic changes that activate oncogenes and inactivate tumor suppressor genes. However, unlike other common genetic alterations found in spontaneous tumors, such as p53 and $\mathrm{K}$-ras mutations, prostate cancer displays a high level of heterogeneity between individuals and the tu- mors themselves ${ }^{18}$. This diversity suggests that there is no dominant molecular pathway leading to the disease, and it is likely that other factors such as prostate infection and inflammation, and possibly dietary considerations also play a role. Advanced age is scientifically relevant as one of the most significant risk factors for prostate cancer ${ }^{19,20}$.

Recently, exposure to environmental factors such as infectious agents, dietary carcinogens and hormonal imbalances are believed to facilitate prostate damage, resulting in chronic inflammation and development of regenerative lesions referred to as proliferative inflammatory atrophy (PIA), a precursor to prostatic intraepithelial neoplasia (PIN) lesions and subsequently to prostatic adenocarcinoma. Multifocal areas of epithelial atrophy are frequently found in radical prostatectomy specimens and are often associated with either acute or chronic inflammatory infiltrates. Interestingly, focal areas of epithelial atrophy were found in the prostate of aged individuals ${ }^{21,22}$. The epithelial cells in these areas exhibit a high proliferative index suggesting repopulation of the injured luminal cells from prostatic stem cell within the basal cell compartment ${ }^{23}$. The regeneration of cells within this inflammatory setting increases the risk of somatic genome alterations, as evidenced by hypermethylation and telomere shortening $^{24,25}$. The outcome of these molecular changes can inhibit genome protection mechanisms and increase genetic instability. These changes are frequently associated with prostate tumorigenesis and progression from high-grade PIN to early prostate cancer formation, with many potentially linked to TGFß-mediated signaling pathways ${ }^{27-29}$. Further mutations are required for the transition from an early prostate carcinoma to androgen-independent growth and are probably selected for in cases when androgens are limited (such as following androgen-deprivation therapy). By far the most studied mutational change in advanced carcinoma and metastatic disease is contained within the androgen receptor (AR) when genetic alterations result in AR over-expression leading to androgen-independent growth ${ }^{30}$.

The AR is well established as a critical mediator of late stage prostate epithelial cancer growth, and targeting AR and its signaling pathway is a focus of the management for advanced disease. Specifically, medical castration and/or treatment with AR antagonists results in declining serum levels of PSA and tumor regression in most patients ${ }^{31}$. 
In clinical settings, as well as in animal and cellular models of castrate environment, disease recurrence and progression is correlated with re-expression of PSA and the evolution of mechanisms that facilitate (or indeed amplify) AR activity and AR-driven epithelial growth ${ }^{31}$. Unfortunately, the critical role played by AR in directly mediating the growth and survival of metastatic epithelial cells has led to some very common misconceptions about the role of AR in the normal prostate environment. Specifically, as described in more detail in the section below, AR expression in epithelial cells is not essential for either development or survival of normal prostate epithelium. Instead, it is the action of AR in stromal cells and its regulation of paracrine mediators that is critical for normal prostate epithelial survival, even in the early stages of prostate cancer.

\section{Early TGFß and Androgen Receptor in Stromal-Epithelial Interactions}

Expression of the AR in the murine urogenital sinus mesenchyme (UGM) together with sufficient levels of the principal testosterone metabolite DHT is essential for the formation of the prostate. This combination results in proliferation of urogenital sinus epithelial (UGE) cells into epithelial buds, followed by columnar cyto-differentiation to form the mature ductal structures. The lack of AR expression in UGE does not affect this process, whereas loss of AR in UGM results in UGE differentiation into vaginal-like epithelia ${ }^{32}$. Castration (androgen ablation) results in almost complete involution of the ductal epithelial cell component of the prostate with minimal effect on the stroma, a process fully reversible by testosterone supplementation that regenerates and repopulates ductal prostate with epithelial cells. These findings indicate the essential role of mesenchymal AR-directed paracrine signals in the fate and maintenance of prostate epithelium $^{33,34}$.

Together with other soluble factors, TGFß is a key mediator of development and homeostatic balance in the prostate, acting predominantly to elicit differentiation, promote apoptosis and limit proliferation of epithelial cells, and to mediate differentiation and patterning of stroma ${ }^{35-38}$. During intense prostate organogenesis, TGFß family members such as activin A are highly expressed by UGM and smooth muscle cells,
Table 1. TGFß1 role and activity in normal prostate cells and prostate carcinogenesis

\begin{tabular}{|c|c|}
\hline $\begin{array}{l}\text { Role in normal } \\
\text { prostate cells } \\
\text { and development }\end{array}$ & $\begin{array}{l}\text { Cellular differentiation } \\
\text { Inhibition of proliferation } \\
\text { Induction of apoptosis } \\
\text { Maintaining dormancy } \\
\text { of prostatic stem cells } \\
\text { Mediates differentiation and } \\
\text { patterning of stroma }\end{array}$ \\
\hline $\begin{array}{l}\text { Early events } \\
\text { in prostate cancer } \\
\text { progression }\end{array}$ & $\begin{array}{l}\text { Increased expression of TGFß1 } \\
\text { in stroma } \\
\text { Increased responsiveness of } \\
\text { TGFß1 in stroma } \\
\text { Increased expression of TGFß1 } \\
\text { in epithelium } \\
\text { Loss of TGFß responsiveness } \\
\text { in epithelium }\end{array}$ \\
\hline $\begin{array}{l}\text { Increased AR } \\
\text { and AR action } \\
\text { in epithelial cells } \\
\text { in prostate cancer } \\
\end{array}$ & $\begin{array}{l}\text { Diminished expression } \\
\text { of TGFßRII receptor, promoting } \\
\text { resistance to TGFß induced } \\
\text { apoptosis }\end{array}$ \\
\hline $\begin{array}{l}\text { Increased TGFß1 } \\
\text { levels in stroma }\end{array}$ & $\begin{array}{l}\text { Stromal expansion } \\
\text { Fibroblast-myofibroblast } \\
\text { transdifferentiation } \\
\text { Angiogenesis, extracellular matrix } \\
\text { remodeling } \\
\text { Epithelial-mesenchymal transition } \\
\text { Facilitation of metastatic spread }\end{array}$ \\
\hline $\begin{array}{l}\text { Increased TGFß1 } \\
\text { levels in stroma }\end{array}$ & $\begin{array}{l}\text { Stromal expansion } \\
\text { Inhibition of T cell proliferation } \\
\text { Suppression of tumor } \\
\text { immunosurveillance }\end{array}$ \\
\hline
\end{tabular}

$\mathrm{AR}=$ androgen receptor; $\mathrm{TGF} \beta=$ transforming growth factor beta; TGFß1 = transforming growth factor beta 1 ; TGFßRII $=$ transforming growth factor beta receptor type II

while it is the TGFß receptors that are expressed predominantly at this time in the urogenital sinus and carried through to the mature prostate epithelium.

Importantly, differentiation of mesenchymal cells depends on the coordinated action, and perhaps direct interactions, of AR and TGFß1 in stromal cells. In the prostate, the addition of activin A results in the inhibition of epithelial ductal branching and elongation, as well as expansion of stroma ${ }^{35}$, thus demonstrating the divergent effects of TGFß family members on mature prostate cell populations (Table 1). 
It is worth noting here that disruption of TGFß1 related pathways has been shown to be involved in the carcinogenesis of cancers in other tissues as well. In the carcinogenesis of colon adenocarcinoma, for instance, TGFß1 levels can be greatly influenced by endogenous and exogenous factors. Interestingly, 4-hydroxynonenal (HNE) demonstrated marked ability to up-regulate expression and synthesis of TGFß1 which is, in turn, a major negative regulatory factor in controlling cell proliferation. In addition, $\mathrm{HNE}$ exhibits anti-proliferative effects by up-regulating the c-Jun-N-terminal kinase (JNK) (member of the mitogen-activated protein kinase family [MAPKs]). A decrease in both HNE and TGFß1 is found in colon cancer cells, and is postulated to provide a fertile environment for neoplastic progression ${ }^{33-35}$.

\section{Direct Interactions and Breakdown in Androgen Receptor and TGFß Signaling in Prostate Cancer}

Evidently, TGFß and AR signaling pathways are coordinated mediators of the homeostatic balance between mesenchymal and epithelial cells in the mature prostate environment. Therefore, breakdown in these interactions is a key component of prostate cancer progression. Following initiation of the tumorigenic process in epithelium, there are three critical early events in prostate cancer progression that could be predicted to have dramatic and synergistic consequences for the prostate microenvironment, as follows: (i) increased expression of TGF $\beta$ in both stroma and epithelium; (ii) an increase in epithelial AR content and a decrease in AR levels in stroma that synergistically predict subsequent aggressive lethal metastatic disease; and (iii) loss of TGFß responsiveness in epithelium ${ }^{36}$ (Table 1).

Decreased stromal AR will precipitate loss in homeostatic control of epithelium via changes in the expression of soluble factors. In turn, increased AR and AR action in epithelial cells has several important consequences, including stimulating the production of TGFß and other soluble factors such as platelet-derived growth factor (PDGF), directly down-regulating, at transcription level, the expression of the TGFßRII receptor, promoting resistance to TGFß induced apoptosis ${ }^{3,35,36}$.

In addition, cancer cells often develop the capacity to utilize increased AR signaling for enhanced intra- crine growth regulation. The loss of TGFßRII expression in epithelium, either transcriptionally, or later via gene methylation silencing, induces TGFß insensitivity in those cells and promotes metastatic spread ${ }^{37-39}$. However, increased TGFß levels in stroma stimulate stromal expansion, fibroblast-myofibroblast transdifferentiation, angiogenesis, extracellular matrix remodeling, degradation, and EMT, thus resulting in facilitation of metastatic spread ${ }^{40}$.

Direct physical interactions have been observed in the TGFß and AR signaling pathways, and specifically with respect to the SMAD 3/4 downstream mediators of the TGFß response. In cells of non-prostatic origin, interaction between the carboxyl-terminal $\mathrm{MH} 2$ domain of SMAD 3 and the amino terminal domain of AR repress DHT-mediated AR activity. In contrast, in prostate cancer cells, the interaction of SMAD3 or SMAD 4 with the AR increases the DHT-mediated AR transactivation response while co-expression of both SMAD3 and SMAD 4 represses it ${ }^{41-43}$. Conversely, the introduction of exogenous AR into AR negative prostate cells reduces the TGFß1/ SMAD transcriptional response and prevents TGFß1 induced growth inhibition and apoptosis ${ }^{44}$. In stromal cells, AR and TGFß action converge on Hic5/ARA 55, which acts both as a stroma-specific AR transcriptional co-regulator and, via interaction with SMAD 3 and SMAD 7, a negative regulator of TGFß respons$\mathrm{es}^{50-52}$. The loss of Hic5 expression in stroma is a prognostic factor of prostate cancer progression and metastasis $^{53}$, and could be predicted to limit stromal AR activity and enhance stromal responses to TGFß with consequences as detailed above.

Overall, these data indicate that a direct crosstalk between TGFß and AR signaling pathways may serve both to enhance TGFß responsiveness in stroma and AR activity in epithelium. A net effect is accelerated cancer cell growth.

\section{Prostate Response to Androgen Ablation and TGFß}

Castration of male mice results in an increase in TGFß levels and signaling that reaches a peak at 8 days, followed by prostatic epithelial apoptosis ${ }^{38,53}$. The level and/or expression of AR in prostate epithelial cells does not affect the degree of apoptosis; instead, the level of DHT-occupied AR in adjacent stromal 
cells critically maintains growth factors that repress both their own TGFß1 expression, as well as apoptotic pathways in adjacent epithelial cells via TGFßRII down-regulation ${ }^{38,44-46}$. Therefore, when androgens are limited, TGFß1 is up-regulated and luminal epithelial cells are lured into apoptotic cell death via enhanced expression of TGFßRII receptors and suppression of the cell survival $\mathrm{Wnt} / \mathrm{\beta}$-catenin signaling cascade, which has recently been shown to induce ductal regression ${ }^{54}$. This effect exhibited temporal and spatial localization, as regression of distal ducts occurred in coordination with diminishing androgen signaling, whilst the viability of proximal prostate tissue was maintained. This is of particular importance, as Wnt/ $\beta$-catenin pathway has an important role during the onset and progression of colorectal cancer and maintains the stem cell phenotype within the proximal prostate tissue.

Overall, the breakdown in normal AR action and reciprocal paracrine signaling between epithelia and stroma results in progressive de-differentiation and proliferation of both cellular compartments, which in turn potentiates a vicious cycle of altered signaling and cellular change ${ }^{54,55}$. Disruption of this complex network of interactions can alter the overall balance of stromal-epithelial signals with net result of uncontrolled epithelial cell growth. The result is a prostate cellular microenvironment in which AR and TGFß signaling systems are completely distinct from that of the normal prostate (Table 1). The most significant changes are a decrease in reliance of cancer epithelia on stroma for proliferative (and survival) stimuli, and the evolution in the epithelium of a powerful and independent intracrine androgen/AR growth promoting pathway. Furthermore, understanding the paracrine interactions of TGFß/androgen and Wnt signaling ${ }^{56}$ that operate between the stromal and epithelial compartments within regression and regeneration of prostate may generate therapies capable of targeting both androgen-dependent and androgen-independent prostate cancer.

\section{Interactions between TGF $\beta$ and Prostate Stem Cells in a Recurrent Prostate Cancer}

The concept that a population of stem cells resided within the prostate was first proposed to explain the seemingly endless ability of prostatic tissue to regress and regenerate during androgen cycling experiments ${ }^{4}$. Further experiments indicated that these prostate stem cells (PSC) resided within an identified stem cell niche localized to the basal cell layer within the region of the gland proximal to the urethra ${ }^{52-69}$. The existence of PSC has been investigated in experiments where a delineated stem cell population, predominantly basal in origin, was shown to have functional prostate regenerative and self-renewal capacity in vivo, which remarkably could be achieved from a single grafted cell ${ }^{53}$. The PSC population has been updated and includes rare castrate-resistant cells of luminal origins, which are capable of prostate regeneration from single cell grafts $^{55}$. These studies verified the importance of stem cells for tissue re-growth and repair.

The PSC niche exhibits an architecture, which includes a thick band of smooth muscle cells that secrete high levels of TGF $\beta^{11,51}$. PSC are anchored within the niche by expression of the surface marker CD49f or integrin a6, which, when paired with either $ß 1$ or $ß 4$, can form an integrin receptor that binds to its ligand laminin, a protein found in its basement membrane and extracellular matrix (ECM $)^{53,57}$. Integrin ligation itself is directly involved in signal transduction and can reportedly influence autocrine TGFß synthesis and its downstream effects ${ }^{58,59}$. Proliferation of PSC is regulated by a balance between the inhibitory effects of TGFß and other mitogenic factors. Furthermore, PSC protect from the apoptotic-inducing effects of a high local concentration of TGFß by cellular expression of Bcl- $2^{11}$. As stem cell differentiation often occurs after departure from the basement membrane, localization of PSC within the TGFß-producing stem cell niche is important in maintaining stem cell quiescence ${ }^{11}$. Tumor cell dissemination occurs early in disease progression for many cancers. The vast majority do not establish metastases ${ }^{60,61}$, and only a small proportion exhibit the self-renewal properties required for metastatic colonization ${ }^{62,63}$. This has focused recent attention on the likelihood that tumors themselves contain cells with tumor-initiating capacity (cancer stem cells). Much of the evidence for this has come from studies of human acute myleoid leukemia and solid tumors such as breast, brain and colon, where the tumorigenic potential was shown to reside in a rare subpopulation of cells expressing markers that overlap with the respective normal tissue stem cells but differ from the 
bulk of the tumor ${ }^{62-67}$. Similarly, the identification and isolation of human prostate cancer stem cells (PCSC) has been achieved with evidence of self-renewal, proliferation and differentiation capacities that recapitulate the original tumor phenotype ${ }^{68,69}$. Whilst the origin of PCSC remains to be fully elucidated, primary candidates are oncogenic mutations within the normal tissue stem cell compartment ${ }^{69,70}$, or more mature progenitor cells that regain some self-renewal and regenerative properties following transformation ${ }^{71}$.

This is the indication of a mutated stem cell acting as a cell origin for prostate cancer ${ }^{55}$.

This transient response of human prostate tumors to androgen-ablation therapy has led to the speculation that recurrent disease arises from this small population of PCSC. Moreover, since normal PSC clearly exhibit androgen independence ${ }^{52,53}$, it is postulated that the dramatic tumor regression brought by androgen-ablation may actually stimulate similarly androgen-independent PCSC to repopulate the tumor with androgen-independent cells, thus leading to emergence of androgen-refractory prostate cancer, followed by metastasis. As TGFß signaling is highly relevant to the transcriptional program of PSC, which includes maintenance of quiescence ${ }^{11,72}$, and has an essential role in maintaining the undifferentiated state of mesenchymal stromal cells in the reactive stroma of prostate cancer ${ }^{73}$, aberrant control of such signaling pathways may be responsible for the propagation and maintenance of cancer stem cells. Furthermore, recent evidence indicates that TGFß-mediated EMT during cancer progression can include cells exhibiting stem cell properties resulting in a dramatic increase in both invasiveness and metastatic activity ${ }^{74-76}$.

The suggestion that long lived stem cells with regenerative capacity are involved in prostate tumorigenesis requires thorough investigation to identify therapies that target not only androgen-dependent tumor cells but also androgen-independent PCSC. Strategies designed to target only rare PCSC will likely involve disruption of TGFß-signaling pathways and/or mediated effects but should be combined with established agents that target androgen-sensitive cells. Further research into PCSC and essential signaling pathways can achieve positive outcomes for development of future hormone-based strategies for the treatment of prostatic disease.

\section{Prostate Tumorigenesis and TGFß-Mediated Immune Invasion}

The discovery of several prostate tumor-specific antigens has driven the development of novel passive and active immunotherapeutic approaches aimed at destruction of the prostate gland ${ }^{77}$. Immune reactivity and damage is theoretically possible as demonstrated in some forms of prostatitis ${ }^{78}$, and experimentally by $\mathrm{T}$ cells activated by immunization with prostate-specific proteins $^{79-81}$. However, attempts to validate these approaches in the clinical environment has led to at best modest induction in tumor-specific $\mathrm{T}$ cell responses in some patients, with most trials showing limited impact on important clinical outcomes such as tumor regression and patient survival ${ }^{82}$. The failure to induce robust anti-tumor clinical responses may be due to many reasons, such as not the least being suboptimal antigen presentation, production of immunosuppressive cytokines, $\mathrm{T}$ cell dysfunction, induction of regulatory $\mathrm{T}$ cell populations, and perhaps most importantly, timing of attempts to induce anti-tumor immunity ${ }^{82,83}$. The first step for developing tumors is to evade immune surveillance ${ }^{84}$, and as all tumors start as a small cluster of cells at one location, local immune suppression is all that is required. Over time, local suppression may generalize into systemic immunity and therefore protect tumor metastases from eradication. Much circumstantial evidence attributes an active immunosuppressive nature to the prostate, particularly in early tumorigenesis. Studies have shown the ability to induce a prostate antigen-specific CD8+ $\mathrm{T}$ cells response in vivo, with lytic activity in vitro, however, most indicate a lack of damage to prostate tissue ${ }^{84,85}$. The mentioned data are associated with the inability of proliferating prostate antigen-specific $\mathrm{T}$ cells to develop effector function, an effect completely dependent on the presence of dendritic cells (DC) ${ }^{86}$. This suggests that a general property of developing prostate tumors is to selectively recruit suppressive DC, or convert stimulatory $\mathrm{DC}$ into suppression for antigen presentation to antigen-specific $\mathrm{T}$ cell in an inhibitory context, thus resulting in rapid induction of tolerance.

The TGFß plays a role in suppression of tumor immunosurveillance via inhibition of $\mathrm{T}$ cell proliferation, which was perhaps best demonstrated by the use of transgenic $T$ cell that had been rendered insensitive to the effects of TGFß by transgenic expression of a 
dominant negative TGFß type II receptor (dn TGFßRII), which has no signal transduction capabilities ${ }^{87}$. These cells were capable of proliferating more vigorously than others sensitive to the effects of TGFß, and exhibited an enhanced effector function in vivo, including the ability to contain tumor growth and limit tumor metastasis via CD4+ T helper cell-dependent priming of cytotoxic T lymphocytes (CTLs) ${ }^{88,89}$. Similarly, radiation bone-marrow chimeric mice, which were reconstituted with TGFß-insensitive bone-marrow and then challenged with melanoma or prostate cancer cell lines, exhibited $70 \%-80 \%$ rates of inhibition of tumor enlargement, which was shown to depend in part on effective CTL responses ${ }^{90}$. These findings, along with the lymphoproliferative disorders observed in mice deficient in TGFß191, or in mice with CD8+ T cells expressing dnTGFßRII ${ }^{92}$, confirm the role of TGFß-signaling in influencing $\mathrm{T}$ cell proliferation and overall $\mathrm{T}$ cell homeostasis.

\section{Type III TGF-ß Receptor Is Probably a Novel Tumor Suppressor}

The TGFß signaling in $\mathrm{T}$ cells is important for regulation of $\mathrm{T}$ cell immunity and tolerance. However, type III TGFß receptor (TGFßRIII) has recently been implicated in the regulation of epithelial tumor progression and suggested to have a tumor suppressor role. TGFßRIII is the most abundantly expressed TGFß-family receptor with a high affinity, thus regulating the interaction and signaling through other TGFß superfamily signaling receptors ${ }^{93}$. Its essential importance in development is highlighted by embryonic lethality in TGFßRIII null mice ${ }^{93}$ with extracellular cleavage producing a soluble extracellular domain capable of antagonizing TGFß signaling ${ }^{94}$. In many epithelial cancers, a reciprocal correlation exists between a down-regulated TGFßRIII expression and an increase in TGFß1 production ${ }^{95}$. In particular, expression of TGFßRIII is frequently reduced or lost in prostate cancer specimens compared with medium to high levels of TGFßRIII staining in all non-neoplastic prostate epithelial tissue. This loss of expression is correlated with metastatic progression and PSA recurrence is suggestive of a novel tumor suppressor function. In vivo data suggested that the expression of TGFßRIII in prostate cancer cell lines alone was enough to inhibit both cell migration and invasiveness ${ }^{95,96}$, via inhibition of directional persistence ${ }^{96}$. These results suggest that loss of TGFßRIII expression may be a common mechanism through which prostate cancer cells escape TGFß-mediated tumor suppression ${ }^{95,96}$.

\section{Conclusion}

To date, there are no clinical trials specifically aimed at testing the efficiency of TGFß inhibition in cancer, although similar compounds to those described above have been tested in preclinical studies with varying results. As TGFß plays an intimate role in normal prostate development and function, as well as contrasting temporal and spatial roles during the progression of prostate cancer, targeting TGFß remains logical. However, as their functions intersect with many other developmental, intrinsic signaling and survival pathways, targeting TGFß for prostate cancer therapy will require complete understanding of the implications of administering such a therapy, particularly at specific times during tumorigenesis. For instance, as we stage earlier clinical prostate cancer intervention, we must recognize that the mechanisms of androgen ablation will be distinct in the early cancerous state compared with advanced or metastatic disease. Furthermore, these tumor survival pathways are also dependent on host stromal cells for growth defense, as well as for supporting tumor growth. Therefore, treatments that target both the stroma and the tumor may be a promising therapeutic approach. Perhaps the most exciting aspect of potential TGFß therapy is the investigation into cancer stem cells where parallel studies of stem cells and cancer stem cells have recently revealed both surface markers ${ }^{85}$, and drug sensitivities ${ }^{86,87}$ unique to the latter. This suggests that targeted therapeutics may be developed for cancer stem cells that will not damage the normal stem cells, and if delivered in the context of TGFß inhibition, may possibly induce both tumor immunity and destruction of cancer stem cells by reducing the local effectiveness of the prostate protective stem cell niche. This may also be effective at common sites of metastasis, such as the bone, where active TGFß released from the bone resorption site directly controls mesenchymal stem cell migration ${ }^{88}$.

We must improve our understanding of all aspects of the TGFß-signaling nexus in prostate cancer to make successful future therapy regimens applicable. 
Otherwise, active interventions may lead not only to a limited clinical benefit but paradoxically may even result in making the patient more susceptible to this disease.

\section{References}

1. American Cancer Society. Cancer Facts \& Figures 2009. Atlanta: American Cancer Society, 2009.

2. Kelly RW, Critchley HO. Immunomodulation by human seminal plasma: a benefit for spermatozoon and pathogen? Hum Reprod. 1997;12:2200-7.

3. Robertson SA, Ingman WV, O'Leary S, et al. Transforming growth factor beta - a mediator of immune deviation in seminal plasma. J Reprod Immunol. 2002;57:109-28.

4. Issacs JT. In benign prostate hyperplasia. Rodgers $\mathrm{CH}$, et al., eds. 1985; Vol 2:85-94.

5. Russell PJ, Bennett S, Stricker P. Growth factor involvement in progression of prostate cancer. Clin Chem. 1998;44:705-23.

6. Danielpour D. Functions and regulation of transforming growth factor-beta (TGF-beta) in the prostate. Eur J Cancer. 2005;41:846-57. doi: 10.1016/j.ejca.20014.12.027

7. Blobe GC, Schiemann WP, Lodish HF. Role of transforming growth factor beta in human disease. N Engl J Med. 2000; 342:1350-8. doi: 1056/NEJM200005043421807

8. Li MO, Wan YY, Sanjabi S, et al. Transforming growth factorbeta regulation of immune responses. Annu Rev Immunol. 2006;24:99-146.

doi: 10.1146/annurev.immunol.24.021605.090737

9. Massague J. TGF beta in cancer. Cell. 2008;134:215-30. doi: 10.1016/j.cell.2008.07.001

10. Moustakas A, Heldin CH. Signaling networks guiding epithelial-mesenchymal transitions during embryogenesis and cancer progression. Cancer Sci. 2007;98:1512-20. doi. 10.1111/j.1349-7006.2007.00550.x

11. Salm SN, Burger PE, Coetzee $\mathrm{S}$, et al. TGF-(beta) maintains dormancy of prostatic stem cells in the proximal region of ducts. J Cell Biol. 2005;170:81-90. doi: 10.1083/jcb.200412015

12. Stravodimos K, Constantinides C, Manousakas T, et al. Immunohistochemical expression of transforming growth factor beta 1 and nm-23 H1 antioncogene in prostate cancer: divergent correlation with clinicopathological parameters. Anticancer Res. 2000;20:3823-8.

13. Shariat SF, Kattan NW, Traxel E, et al. Association of pre- and postoperative plasma levels of transforming growth factor beta(1) and interleukin 6 and its soluble receptor with prostate cancer progression. Clin Cancer Res. 2004;10:1992-9.

14. Wikstrom P, Damber J, Bergh A. Role of transforming growth factor-beta1 in prostate cancer. Microsc Res Tech. 2001;52: 411-9.

15. Kim IY, Ahn HJ, Lang S, et al. Loss of expression of transforming growth factor-beta receptors is associated with poor prog- nosis in prostate cancer patients. Clin Cancer Res. 1998;4: 1625-30.

16. Lee HM, Timme TL, Thompson TC. Resistance to lysis by cytotoxic T cells: a dominant effect in metastatic mouse prostate cancer cells. Cancer Res. 2000;60:1927-33. doi: 10.1158/0008-5472.CAN-09-2919

17. Matthews E, Yang T, Janulis L, et al. Down-regulation of TGFbeta1 production restores immunogenicity in prostate cancer cells. Br J Cancer. 2000;83:519-25.

18. Abate-Shen C, Shen MM. Molecular genetics of prostate cancer. Genes Dev. 2000;14:2410-34.

19. Wang W, Bergh A, Damber JE. Morphological transition of proliferative inflammatory atrophy to high-grade intraepithelial neoplasia and cancer in human prostate. Prostate. 2009; 69:1378-86. doi: 10.1002/pros.20992

20. De Marzo AM, Platz EA, Sutcliffe S, et al. Inflammation in prostate carcinogenesis. Nat Rev Cancer. 2007;7:256-69. doi: $10.1038 / \mathrm{nrc} 2090$

21. Franks LM. Atrophy and hyperplasia in the prostate proper. J Pathol Bacteriol. 1954;68:617-21.

22. Rich AR. Classics in oncology. On the frequency of occurrence of occult carcinoma of the prostate: Arnold Rice Rich, M.D., Journal of Urology 33:3, 1935. CA Cancer J Clin. 1979;29: 115-9.

23. Van Leenders GJ, Gage WR, Hicks JL, et al. Intermediate cells in human prostate epithelium are enriched in proliferative inflammatory atrophy. Am J Pathol. 2003;162:1529-37. doi: 10.1016/S0002-9440(10)64286-1

24. Meiers I, Shancks JH, Bostwick DG. Glutathione S-transferase pi (GSTP1) hypermethylation in prostate cancer: review 2007. Pathology. 2007;39:299-304.

25. Meeker AK. Telomeres and telomerase in prostatic intraepithelial neoplasia and prostate cancer biology. Urol Oncol. 2006;24:122-30. doi: 10.1016/j.urolonc.2005.11.002

26. De Marzo AM, DeWeese TL, Platz EA, et al. Pathological and molecular mechanisms of prostate carcinogenesis: implications for diagnosis, detection, prevention, and treatment. J Cell Biochem. 2004;91:459-77. doi: 10.1002/jcb.10747

27. Chen CR, Kang Y, Siegel PM, Massague J. E2F4/5 and p107 as Smad cofactors linking the TGF beta receptor to C-myc repression. Cell. 2002;110:19-32.

28. Gomis RR, Alacron C, Nadal C, et al. C/EBPbeta at the core of the TGFbeta cytostatic response and its evasion in metastatic breast cancer cells. Cancer Cell. 2006;10:203-14.doi: 10.1016/j.ccr.2006.07.019

29. Assinder SJ, Dong Q, Kovacevic Z, Richardson DR. The TGFbeta PI3K/Akt and PTEN pathways: established and proposed biochemical integration in prostate cancer. Biochem J. 2009; 417:411-21. doi: 10.1042/BJ20081610

30. Chmelar R, Buchanan G, Need EF, et al. Androgen receptor coregulators and their involvement in the development and progression of prostate cancer. Int J Cancer. 2007;120:719-33. doi: $10.1002 /$ ijc. 22365 
31. Scher HI, Buchanan G, Gerald W, et al. Targeting the androgen receptor: improving outcomes for castration-resistant prostate cancer. Endocr Relat Cancer. 2004;11:459-76.

32. Cunha GR, Lung B. The possible influence of temporal factors in androgenic responsiveness of urogenital tissue recombinants from wild-type and androgen insensitive (Tfm) mice. J Exp Zool. 1978;205:181-93.

33. Donjacour AA, Cunha GR. Assessment of prostatic protein secretion in tissue recombinants made of uregenital sinus mesenchyme and urothelium from normal or androgen-insensitive mice. Endocrinology. 1993;132:2342-50.

34. Cunha GR, Young P. Inability of Tfm (testicular feminization) epithelial cells to express androgen-dependent seminal vesicle secretory proteins in chimeric tissue recombinants. Endocrinology. 1991;128:3293-8.

35. Vizio B, Poli G, Chiarpotto E, Biasi F. 4-Hydroxynonenal and TGF- $\beta 1$ concur in inducing antiproliferative effects on the Caco-2 human colon adenocarcinoma cell line. BioFactors. 2005;24: 237-46. doi: 10.1002/biof.5520240128

36. Riccardelli C, Choong CS, Buchanan G, et al. Androgen receptor levels in prostate cancer epithelial and peritumoral stromal cells identify non-organ confined disease. Prostate. 2005;63: 19-28. doi: 10.1002/pros.20154

37. Tuxhorn JA, Ayala GE, Smith MJ, et al. Reactive stroma in human prostate cancer: induction of myofibroblast phenotype and extracellular matrix remodeling. Clin Cancer Res. 2002; 8:2912-23. doi: 10.1158/0008-5472.CAN-07-6289

38. Song K, Wang H, Krebs TL, et al. Androgenic control of transforming growth factor-beta signaling in prostate epithelial cells through transcriptional suppression of transforming growth factor-beta receptor II. Cancer Res. 2008;68:8173-82. doi: 10.1158/0008-5472.CAN-08-2290

39. Tu WH, Thomas TZ, Masumori N, et al. The loss of TGF-beta signaling promotes prostate cancer metastasis. Neoplasia. 2003;5:267-77. doi:10.101 6/S1476-5586(03)80058-1

40. Zhao H, Shiina H, Greene KL, et al. $\mathrm{CpG}$ methylation at promoter site-140 inactivates TGF beta 2 receptor gene in prostate cancer. Cancer. 2005;104:44-52.

41. Hayes SA, Zernegar M, Sharma M, et al. SMAD3 represses androgen receptor-mediated transcription. Cancer Res. 2001; 61:2112-8.

42. Kang HY, Huang KE, Chang SY, et al. Differential modulation of androgen receptor-mediated transactivation by Smad3 and tumor suppressor Smad4. Biol Chem. 2002;277:43749-56. doi: 10.1074/jbc.M205603200

43. Zhu ML, Partin JV, Bruckheimer EM, et al. TGF-beta signaling and androgen receptor status determine apoptotic crosstalk in human prostate cancer cells. Prostate. 2008;68:287-95. doi: $10.1002 /$ pros. 20698

44. Chipuk JE, Cornelius SC, Pultz NJ, et al. The androgen receptor represses transforming growth factor-beta signaling through interaction with Smad3. J Biol Chem. 2002;277:1240-8. doi: 10.1074/jbc.M108855200
45. Wang H, Song K, Krebs TL, et al. Smad7 is inactivated through a direct physical interaction with the LIM protein Hic-5/ ARA55. Oncogene. 2008;27:6791-805. doi: 10.1038/onc.2008.291

46. Heitzer MD, DeFranco DB. Hic-5/ARA55, a prostrate stroma-specific AR coactivator. Steroids. 2007;72.218-20.

47. Heitzer MD, De Franco DB. Hic-5/ARA55, a LIM domaincontaining nuclear receptor coactivator expressed in prostate stromal cells. Cancer Res. 2006;66:7326-33. doi: 10.1158/00085472.CAN-05-2379

48. Wikstrom P, Marusic J, Stattin P, Bergh A. Low stroma androgen receptor level in normal and tumor prostate tissue is related to poor outcome in prostate cancer patients. Prostate. 2009; 69:799-809. doi: 10.1002/pros.20927

49. Kyprianou N, Isaacs JT. Expression in transforming growth factor-beta in the rat ventral prostate during castration-induced programmed cell death. Mol Endocrinol. 1989;3:1515-22.

50. Wikstrom P,Westin P, Stattin P, et al. Early castration-induced upregulation of transforming growth factor beta1 and its receptors is associated with tumor cell apoptosis and a major decline in serum prostate-specific antigen in prostate cancer patients. Prostate. 1999;38:268-77.

51. Denmeade SR, Lin XS, Isaacs JT. Role of programmed (apoptotic) cell death during the progression and therapy for prostate cancer. Prostate. 1996;28:251-65.

52. Placencio VR, Sharif-Afshar AR, Li X, et al. Stromal transforming growth factor-beta signaling mediates prostatic response to androgen ablation by paracrine Wnt activity. Cancer Res. 2008;68:4709-18. doi: 10.1158/0008-5472.CAN-07-6289

53. Cunha GR, Ricke W, Thomson A, et al. Hormonal, cellular, and molecular regulation of normal and neoplastic development. J Steroid Biochem MolBiol.2004;92:221-36.doi:10.4103/09701591.42610

54. Terry S, Yang X, Chen MW, et al. Multifaceted interaction between the androgen and Wnt signaling pathways and the implication for prostate cancer. J Cell Biochem. 2006;99:402-10. doi: 10.1002/icb.20983

55. English HF, Santen RJ, Isaacs JT. Response of glandular versus basal rat ventral prostatic epithelial cells to androgen withdrawal and replacement. Prostate. 1987;11:229-42.

56. Tsujimura A, Koikawa Y, Salm S, et al. Proximal location of mouse prostate epithelial stem cells: a model of prostatic homeostasis. J Cell Biol. 2002;157:1257-65. doi: 10.1083/ jcb.200202067

57. Lawson DA, Xin L, Lukacs RU, et al. Isolation and functional characterization of murine prostate stem cells. Proc Natl Acad Sci USA. 2007;104:181-6. doi: 10.1073/pnas.0609684104

58. Leong KG, Wang BE, Johnson L, Gao WQ. Generation of a prostate from a single adult stem cell. Nature. 2008;456:804-8. doi: $10.1038 /$ nature 07427

59. Wang X, Kruithof-de Julio M, Economides KD, et al. A luminal epithelial stem cell that is a cell of origin for prostate cancer. Nature. 2009;461:495-500. doi: 10.1038/nature08361 
60. Nemeth JA, Sensibar JA, White RR, et al. Prostatic ductal system in rats: tissue-specific expression and regional variation in stromal distribution of transforming growth factor-beta1. Prostate. 1997;33:64-71.

61. Niessen CM, Hogervorst F, Jaspars LH, et al. The alpha 6 beta 4 integrin is a receptor for both laminin and kalinin. Exp Cell Res. 1994;211:360-7.

62. Juliano RL. Signal transduction by cell adhesion receptors and the cytoskeleton: functions of integrins, cadherins, selectins, and immunoglobulin-superfamily members. Annu Rev Pharmacol Toxicol. 2002;42:283-323. doi: 10.1146/annurev.pharmtox.42.090401.151133

63. Wang D, Sun L, Zborowska E, et al. Control of type II transforming growth factor-beta receptor expression by integrin ligation. J Biol Chem. 1999;274:12840-7.

64. Aguirre-Ghiso JA. Models, mechanisms and clinical evidence for cancer dormancy. Nat Rev Cancer. 2007;7:834-46. doi: $10.1038 / \mathrm{nrc} 2256$

65. Ellis WJ, Pfitzenmaier J, Colli J, et al. Detection and isolation of prostate cancer cells from peripheral blood and bone marrow. Urology. 2003;61:277-81.

66. Chamers AF, Groom AC, Mac Donald IC. Dissemination and growth of cancer cells in metastatic sites. Nat Rev Cancer. 2002;2:563-72. doi: 10.1038/nrc865

67. Sing SK, Hawkins C, Clarke ID, et al. Identification of human brain tumor initiating calls. Nature. 2004;432:396-401. doi: 10.1038 /nature 03128

68. Gu G, Yuan J, Wills M, Kasper S. Prostate cancer cells with stem cell characteristics reconstitute the original human tumor in vivo. Cancer Res. 2007;67:4807-15.

doi: 10.1016/j.clgc.2012.01.002

69. Collins AT, Berry PA, Hyde C, et al. Prospective identification of tumorigenic prostate cancer stem cells. Cancer Res. 2005;65:10946-51. doi: 10.1158/0008-5472.CAN-05-2018

70. Patrawala L, Calhoun T, Schneider- Broussard R, et al. Highly purified CD44+ prostate cancer cells from xenograft human tumors are enriched in tumorigenic and metastatic progenitor cells. Oncogene. 2006;25:1696-708.

doi: 10..1038/sj.onc.1209327

71. Van Leeders GJ, Schalken JA. Stem cell differentiation within the human prostate epithelium: implications for prostate carcinogenesis. BJU Int. 2001;88 Suppl 2:35-42; discussion 49-50.

72. Blum R, Gupta R, Burger PE, et al. Molecular signatures of prostate stem cells reveal novel signaling pathways and provide insights into prostate cancer. PloS One. 2009;4:e5722. doi: 10.1371/journal.pone.0005722

73. Santamaria-Martinez A, Barquinero J, Barbosa-Desnogles A, et al. Identification of multipotent mesenchymal stromal cells in the reactive stroma of a prostate cancer xenograft by side population analysis. Exp Cell Res. 2009;315:3004-13. doi: 10.1016/j.yexcr.2009.05.007

74. Mani SA, Guo W, Liao MJ, et al. The epithelial-mesenchymal transition generates cells with properties of stem cells. Cell. 2008;133:704-15. doi: 10.1016/j.cell.2008.03.027
75. Morel AP, Lievre M, Thomas C, et al. Generation of breast cancer stem cells through epithelial-mesenchymal transition. PloS One. 208;3:e2888. doi: 10.1371/journal.pone.0002888

76. Kabashima A, Higuchi $\mathrm{H}$, Takaishi $\mathrm{H}$, et al. Side population of pancreatic cancer cells predominates in TGF-beta-mediated epithelial to mesenchymal transition and invasion. Int J Cancer. 2009;124:2771-9. doi: 10.1002/ijc.24349

77. Basler M, Groettrup M. Advances in prostate cancer immunotherapies. Drugs Aging. 2007;24:197-221. doi: 10.4172/21559899.1000351

78. Klyushnenkova EN, Ponniah S, Roderiguez A, et al. CD4 and CD8 T-lymphocyte recognition of prostate specific antigen in granulomatous prostatitis. J Immunother. 2004;27:136-46.

79. Fong L, Ruegg CL, Brockstedt D, et al. Induction of tissuespecific autoimmune prostatitis with prostatic acid phosphatase immunization: implications for immunotherapy of prostate cancer. J Immunol. 1997;159:3113.

80. Liu KJ, Chatta GS, Twardzik DR, et al. Identification of rat prostatic steroid-binding protein as a target antigen of experimental autoimmune prostatitis: implications for prostate cancer therapy. J Immunol. 1997;159:472-80.

81. Maccioni M, Rivero VE, Riera CM. Prostatein (or rat prostatic steroid binding protein) is a major autoantigen in experimental autoimmune prostatitis. Clin Exp Immunol. 1998;112:159-65.

82. Ahmad M, Rees RC, Ali SA. Escape from immunotherapy: possible mechanisms that influence tumor regression/progression. Cancer Immunol Immunother. 2004;53:844-54. doi: 10.1007/s00262-004-0540-x

83. Nagaraj S, Gupta K, Pisarev V, et al. Altered recognition of antigen is a mechanism of CD8+ T cell tolerance in cancer. Nat Med. 2007;13:828-35. doi: 10.1038/nm1609

84. Zou W. Regulatory T cell, tumour immunity and immunotherapy. Nat Rev Immunol. 2006;6:295-307. doi: 10.1038/ nri1806

85. Dunn GP, Koebel CM, Schrieber RD. Interferons, immunity and cancer immunoediting. Nat Rev Immunol. 2006;6:836-48. doi: $0.1038 /$ nri1961

86. Lees JR, Charbonneau B, Hayball JD, et al. T-cell recognition of a prostate specific antigen is not sufficient to induce prostate tissue destruction. Prostate. 2006;66:578-90.

87. Gorelik L, Flavell RA. Immune-mediated eradication of tumors through the blockade of transforming growth factor-beta signaling in T cells. Nat Med. 2001;7:1118-22. doi: 10.1038/ nm1001-1118

88. Shah AH, Tabayayong WB, Kundu SD, et al. Suppression of tumor metastasis by blockade of transforming growth factor beta signaling in bone marrow cells through a retroviral-mediated gene therapy in mice. Cancer Res. 2006;62:7135-8.

89. Kulkarni AB, Huh CG, Becker D, et al. Transforming growth factor beta 1 null mutation in mice causes excessive inflammatory response and early death. Proc Natl Acad Sci USA. 1993; 90:770-4. 
90. Compton LA, Potash DA, Brown CB, Barnett JV. Coronary vessel development is dependent on the type III transforming growth factor beta receptor. Circ Res. 2007;101:784-91. doi: 10.1161/CIRCRESAHA.107.152082

91. Lopez-Casillas F, Payne HM, Andres JL, Massague J. Betaglycan can act as a dual modulator of TGF-beta access to signaling receptors: mapping of ligand binding and GAG attachment sites. J Cell Biol. 1994;124:557-68.

92. Hempel N, How T, Cooper SJ, et al. Expression of the type III TGF-beta receptor is negatively regulated by TGF-beta. Carcinogenesis. 2008;29:905-12. doi: 10..1093/carcin/bgn049

93. Turley RS, Finger EC, Hempel N, et al. The type III transforming growth factor-beta receptor, a novel tumor suppressor gene in prostate cancer. Cancer Res. 2007;67:1090-8. doi: 10.1158 /0008-5472.CAN-06-3117

94. Mythreye K, Blobe GC. The type III TGF-beta receptor regulates epithelial and cancer cell migration through beta-arrestin2-mediated activation of Cdc42. Proc Natl Acad Sci USA. 2009;106:8221-6. doi: 10.1073/pnas.0812879106

95. Yilmaz OH, Valdez R, Theisen BK, et al. Pten dependence distinguishes haematopoietic stem cells from leukaemia-initiating cells. Nature. 2006;441:475-82. doi: 10.1038/nature04703

96. Tang Y, Wu X, Lei W, et al. TGF-beta 1-induced migration of bone mesenchymal stem cells couples bone resorption with formation. Nat Med. 2009;15:757-65. doi: 10.1036/nm.1979

Sažetak

\section{TGF-BETA I NASTANAK KARCINOMA PROSTATE}

\section{J. Ahel, N. Hudorović, V. Vičic-Hudorović i H. Nikles}

Svi transformacijski faktori rasta beta (TGFß) su citokini koji reguliraju nekoliko staničnih funkcija kao što su rast, diferencijacija i pokretljivost stanice. Oni također imaju značajnu ulogu u imunosupresiji. Njihova je uloga osobito značajna za normalan razvoj prostate. TGFß je aktivan u regulaciji ravnoteže između proliferacije epitelnih stanica i apoptoze kroz stromalni epitel preko djelovanja androgenog receptora. TGFß štiti i održava matične stanice prostate, značajan čimbenik za regeneraciju tkiva prostate. Do danas publicirani rezultati iznalaze da TGFß ima suprotnu ulogu u nastanku tumora prostate. U ranim fazama razvoja tumora TGFß djeluje kao supresor tumora, dok u kasnijim fazama TGFß postaje tumorski promotor inducirajući proliferaciju, invazivni rast i razvoj metastaza. U ovom preglednom članku opisuju se složene interakcije koje TGFß-posredovani mehanizmi imaju na nastanak tumora prostate, s osobitim naglaskom na mehanizme djelovanja tijekom nastanka karcinoma prostate i naročito tijekom progresije osnovne bolesti.

Ključne riječi: Transformirajući čmbenik rasta beta; Prostata, tumori; Bolest, napredovanje; Receptori, androgeni; Matične stanice 